\title{
SKRINING SPONS POTENSIAL SEBAGAI BIODEGRADATOR HIDROKARBON BERDASARKAN DATA MORFOLOGI
}

\author{
Ismail Marzuki ${ }^{(1)}$, Erniati $^{(2)}$ \\ ${ }^{1}$ Laboratorium Dasar, Teknik Kimia, Fakultas Teknik, Universitas Fajar, \\ ${ }^{2}$ Teknik Sipil, Fakultas Teknik, Universitas Fajar, \\ Jl. Prof. Abdurrahman Basalamah, (Ex. Jl. Racing Center) No. 101, Makassar \\ Sulawesi Selatan, Indonesia, 90231
}

\begin{abstract}
Sea morphological sponge searches that potentially degrade contaminated wastes Poly Aromatic Hydrocarbons (PAH) are important to aim to identify earlier physical features of marine sponge types that potentially reduce the toxicity of PAH. Previous research has shown that a special type of marine sponge marker that may be symbiotic with microorganisms capable of producing enzymes for degradation of PAH, whose body structure contains mucus or its body is protected by a black layer such as mud embodied as mucus. Sponge identification method is done by noting the special sign (color, texture, shape, size and depth of sampling). Then sequentially the sponge morphology identification followed the guidebook. The results of the analysis of four types of sponges, found that the sponge Petrosia (Strongylophora) corticata (Sp 1) in the body there is mucus and Niphates sp (Sp 2) along the surface found a black layer of textured mucus. The structure indicates that the two potential sponges form a symbiont with certain types of bacteria that can destabilize the PAH benzene ring, so that the PAH toxicity level decreases. Hyrtios erectus (Sp3) and Clathria (Thalysias) reinwardti ( $\mathrm{Sp} 4)$ sponges, both of which do not potentially contain bacterial symbionts that can reduce the toxicity of PAH.
\end{abstract}

Keywords: Sponges, symbionts, morphology, degradation, $\mathrm{PAH}$

\section{PENDAHULUAN}

Berbagai jenis spons dapat ditemukan di Kepulauan Spermonde, Sulawesi Selatan. Spons adalah hewan unik metazoa multiseluler, golongan filum Porifera, memiliki perbedaan struktur dengan metazoan lainnya. Sebagian besar tubuh spons berpori, berupa ruang yang berfungsi sebagai saluran sirkulasi air terus menerus, (Marzuki, et al, 2015a; Ismet, et al., 2011). Cara makan spons dengan mengisap dan menyaring air melalui seluruh permukaan tubuh secara aktif, (Romimohtarto, 1999). Umumnya, spons terdiri atas beberapa jenis sel membentuk struktur tubuh dan biomassa. Lapisan luar dinding tubuh spons berupa sel pipih, disebut pinacocytes. Struktur tubuh spon tersusun atas Choanosome, skeleton, spicule, megasclere dan mungkin Oxea. Marine sponges (Porifera) are the oldest metazoan group and characterized as sessile active filter feeders, (Hausmann, et al., 2006). Phylum Porifera terbagi menjadi tiga kelas 'i. e. Calcarea (spons beralkohol dengan spikula kalsium karbonat tiga), Demospongiae (kerangka spikula silika) Demospongiae mengandung sebagian besar spons yang hidup saat ini dan mewakili $85-90 \%$ fauna spons global, (Thakur, et al., 2004). Sel dapat membuka dan menutup dengan adanya kontraksi sekaligus memberi peluang terperangkapnya bakteri dalam tubuh spons yang mencari perlindungan untuk terbebas dari arus gelombang laut, sekaligus bakteri yang terperangkap digunakan spon untuk memproduksi zat (enzim) yang dapat mengurai zat toksik yang terdapat di perairan tempat hidup spons, sekaligus memberi perlindungan spons akibat ancaman kontaminan yang mencemari lingkungan, (Marzuki, et al. 2014; Marzuki, et al., 2015a; Steindler, et al., 2005).

Bagian dalam pinacoderm terdapat mesohyl, yang terdiri dari matriks protein bergelatin yang mengandung skeleton dan sel-sel amoeboid. Lapisan ini berfungsi seperti jaringan ikat pada metazoa lainnya. Skeleton spons demospongia terbentuk dari spikula bersilika dan serat protein spongin. Spikula spons memiliki jenis yang beragam, sehingga dijadikan dasar untuk identifikasi morfologi spons. Spikula berada di dalam mesohyl, namun sering juga ditemukan pada lapisan pinacoderm. Sel-sel amoeboid dapat ditemukan pada mesohyl, dan tersusun dari beberapa jenis sel. Archaeocyt adalah sel berukuran besar dengan nukleus yang besar pula. Sel ini merupakan sel fagositosis dan berperan dalam digesti makanan, serta bersifat totipotent. Sel lainnya adalah collencytes, sclerocytes, dan spongocytes, serta choanocytes, terdapat pada bagian dalam mesohyl, sejajar dengan spongocoel. Sel ini berperan dalam pergerakan air dalam tubuh spons dan untuk menyediakan makanan, (Marzuki, et al., 2014; Ismet, et al., 2011). Beberapa hasil penelitian tentang biodegradasi komponen hidrokarbon dan poli aromatik hidrokarbon yang 
menggunakan mikrosimbion spons laut sebagai material pendegradasi yang telah dipublikasikan, menunjukkan bahwa umumnya mikrosimbion yang dapat mendegradasi hidrokarbon dan PAH adalah isolat dari spons yang memiliki struktur tubuh dengan sel-sel seperti choanosome, skeleton, spicule, megasclere, (Marzuki, et al., 2015b; 2015c; Marzuki, et al., 2017).

\section{METODE PENELITIAN}

\section{Lokasi Pengambilan Sampel Spons}

Titik sampling spons pada Pulau Kodingareng Keke, Kepulauan Spermonde dapat dilihat pada Gambar 1, di bawah:

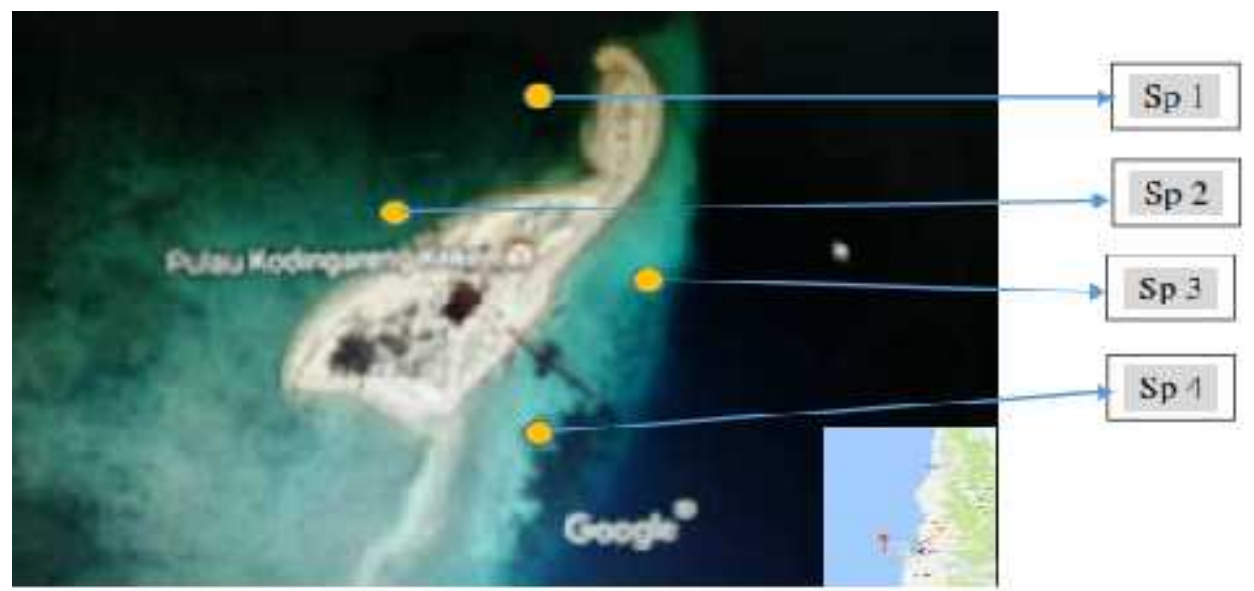

Gambar 1. Peta Lokasi Titik Sampling Spons (Pulau Kodingareng Keke),

Kepulauan Spermonde, Sulawesi Selatan

\section{Metode Pengambilan Sampel}

Data pengamatan lokasi pengambilan sampel spons segar, terdiri atas koordinat, kedalaman, salinitas, $\mathrm{pH}$ dan temperature, disajikan pada Tabel 1. Lokasi sampling adalah sekitar Pulau Kodingareng Keke, wilayah Kecamatan Ujung Tanah Kota Makassa, Sulawesi Selatan. Lokasi tersebut merupakan gugusan Kepulauan Spermonde. Jumlah sampel spons sebanyak 4 jenis dengan kode sampel Sp 1; Sp 2; Sp 3 dan Sp 4 (Gambar 1). Sampel diperoleh menggunakan diving Scuba, lalu direndam dalam formaldehid $4 \%$ sebelum dianalisis lebih lanjut.

\section{Material}

Scuba, kamera di air, GPS, Balance (pembedahan), pisau bedah, forsep, botol (toples), kantong plastik, kotak es, mikroskop set, piala porselen, alu dan lumpang, kaca kimia, kaca pengukur, labu, pipet volume, pipet, Erlenmeyer, keseimbangan analitik, piring panas, corong, pengisap karet, listrik panas, kertas Whatman, oven, freezer, botol BOD, termometer air, kertas universal, salinometer, reaksi hemat, solder cup, centripugacy $1000 \mathrm{rpm}$ dan $4 \mathrm{rpm}$, berhenti arloji, vortex, aliran air laminary, ose ekor, gelas prevarat, autoklaf, filter $0,2 \mathrm{~m}$, blender, haemocitometer.

Contoh Spons, $\mathrm{CH}_{3} \mathrm{OH}$ pa, Air laut steril, Sereal Penyangga Phospat (PBS), Media Air Laut yang Dilengkapi (SWC), media MA, media NA, gliserol 25\%, isolat bakteri (mikrosimbion), $\mathrm{PAH}, \mathrm{NaCl} \mathrm{0,9 \%}$, formalin 4\%, Aquabides, aquades, reagen MTT, DMSO

\section{Prosedur Analisis}

Analisis morfologi sel dengan metode MTT menggunakan mikroskop terbalik, uji, (A) Sel Kultur Sebelum dilakukan inkubasi 24 jam, setelah penambahan reagen MTT selama 4 jam, (B) menggunakan sel kontrol, (C) ekstrak konsentrasi 960 g/ mL, (D) konsentrasi ekstrak sebanyak 7,5 g /mL, (E) kontrol DMSO. Analisis morfologi spons untuk mengetahui jenis dan struktur tubuh spons.

\section{HASIL DAN PEMBAHASAN}

Gambaran lingkungan lokasi sampling spons pada Pulau Kodingareng Keke, Kecamatan Ujung Tanah, Kota Makassar, bagian dari Gugusan Kepulauan Spermonde. Data pengamatan disajikan dalam tabel 1 berikut: 
Tabel 1. Keadaan Lingkungan Lokasi Sampling Spons pada Pulau Kodingareng, Gugusan Kepulauan Spermonde

\begin{tabular}{|c|c|c|c|c|c|}
\hline \multirow{2}{*}{ No } & \multirow{2}{*}{ Pengamatan } & \multicolumn{4}{|c|}{ Kode Sampel } \\
\hline & & Sp 1 & Sp 2 & Sp 3 & Sp 4 \\
\hline \multirow[t]{2}{*}{1} & Koordinat & $S=05^{0} 06^{\prime} 06.76^{\prime \prime}$ & $\mathrm{S}=05^{0} 06^{\prime} 06.54^{\prime \prime}$ & $\mathrm{S}=05^{0} 06^{\prime} 06.81^{\prime \prime}$ & $S=05^{0} 06^{\prime} 06.73^{\prime \prime}$ \\
\hline & & $\mathrm{E}=119^{0} 17^{\prime} 10.66^{\prime \prime \prime}$ & $\mathrm{E}=119^{0} 17^{\prime} 10.62^{\prime \prime \prime}$ & $\mathrm{E}=119^{0} 17^{\prime} 10.72^{\prime \prime \prime}$ & $\mathrm{E}=119^{0} 17^{\prime} 10.62^{\prime \prime \prime}$ \\
\hline 2 & Kedalaman & $3,2 \mathrm{~m}$ & $2,6 \mathrm{~m}$ & $3,7 \mathrm{~m}$ & $4,1 \mathrm{~m}$ \\
\hline 3 & Salinitas & $29,3 \%$ & $29,6 \% \circ$ & $29,5 \% \circ$ & $29,3 \% 0$ \\
\hline 4 & $\mathrm{pH}$ & 7 & 7 & 7 & 7 \\
\hline 4 & Temperatur & $29^{0} \mathrm{C}$ & $30^{0} \mathrm{C}$ & $28^{0} \mathrm{C}$ & $28^{0} \mathrm{C}$ \\
\hline
\end{tabular}

Hasil identifikasi morfologi spons kode sampel Sp 1; Sp 2; Sp 3, dan Sp4, berdasarkan bentuk pertumbuhan, warna fisik, jenis choanosome kerangka spicule yang dikombinasikan dengan keadaan lingkungan pertumbuhan spons dapat disimpulkan bahwa keempat sampel spon yang diperoleh pada Pulau Kadingareng Keke, merupakan spon kelas Demospongiae, ordo, family dan spesies ditunjukkan dalam Tabel 2, berikut:

Tabel 2. Hasil Identifikasi Spesies Spons dengan Metode Analisis Morfologi

\begin{tabular}{|c|c|c|c|c|}
\hline $\begin{array}{l}\text { Kode } \\
\text { Sampel }\end{array}$ & Spesies & Famili & Ordo & Kelas \\
\hline $\mathrm{Sp} 1$ & Petrosia (Strongylophora) corticata & Petrosiidae & Haclosclerida & Demospongiae \\
\hline Sp 2 & Niphates sp. & Niphatidae & Haclosclerida & Demospongia€ \\
\hline Sp 3 & Hyrtios erectus & Thorectidae & Dictyoceratida & Demospongiae \\
\hline Sp 4 & Clathria (Thalysias) reinwardti & Microcionidae & Poeciloslerida & Demospongiae \\
\hline
\end{tabular}

Sumber: Data Primer telah diolah

Karakteristik keempat sampel jenis spons khususnya bentuk pertumbuhan, konsistensi, bentuk permukaan, keberadaan choanosome, kerangka tubuh dan tipe spicule, berturut-turut ditunjukkan pada Gambar 2, 3, 4 dan 5, berikut:

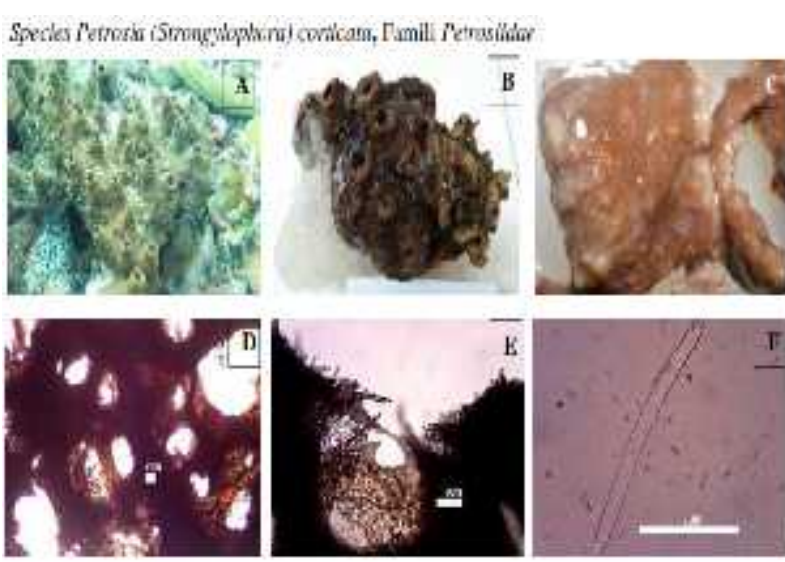

Gambar 2. (A) Bentuk pertumbuhanbergerombol. Kulit berbentuk cerobong memiliki oscular tinggi. bercahaya berwarna coklat muda, (B) Konsistensi: tegas, menunjukkan kekuatan, (C) Permukaan spons yang tidak rata dan berlendir, proyeksi halus, (D) Choanosome dengan kerangka spicule multispicular, (E) Kerangka kurang serat dengan spicule padat dan (F) Spicule: tipe Megasclere: berupa Oksida

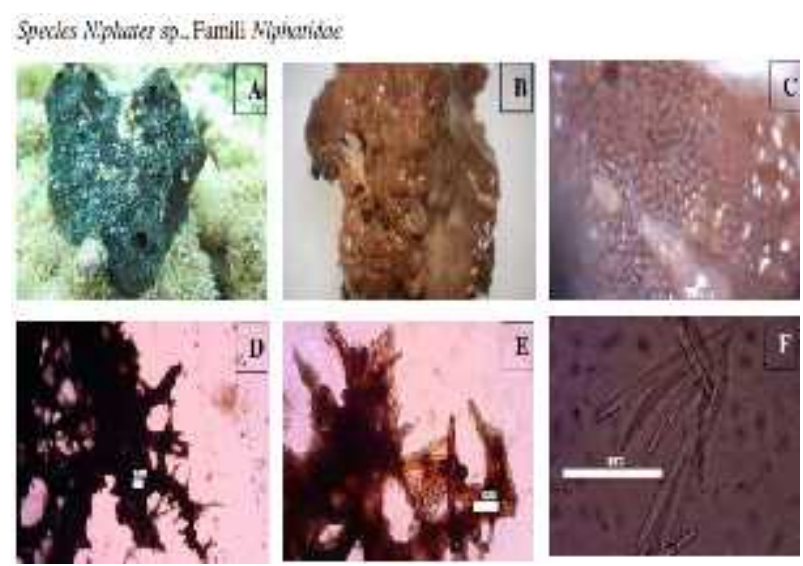

ambar 3. (A) Bentuk pertumbuhan: Sponge melingkar gligthy, dengan oscula ukuran besar, (B) Konsistensi: permukaan licin, ditutupi oleh lumpur seperti lendir.Tubuh yang tidak elastis dan rapuh, (C) Konsistensi: permukaan licin, ditutupi lumpur seperti lumpur. Spel tubuh yang tidak elastis dan rontok, (D) Kerangknya: berupa spicule dengan spidol echinating, (E) Kerangknya membentuk Pilar trapesium dengan serat tinggi, dan (F) Spicule: megasclera oxea kecil. 


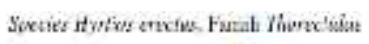
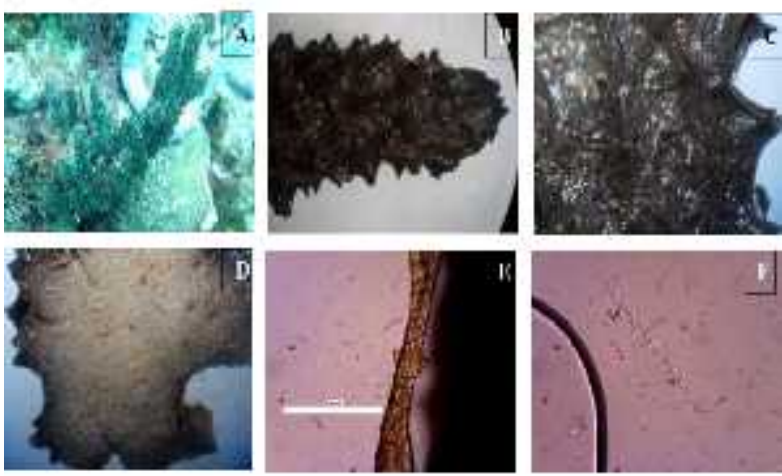

Gambar 4

(A) Bentuk

Pertumbuhan:

spon bercabang Digit. Konsentrat berwarna hitam, (B Karakteristik yang tidak teridentifikasi, tegas, berdagin€ (C) Permukaan berbentuk piramida, (D) Choanosom membentuk bagian potongan tubuh. Berat serat tubu spong, (E) Kerangka menempel berupa serabut, ( $\mathrm{F}$ Spicule: megaplera Substylostyle.

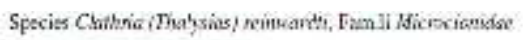
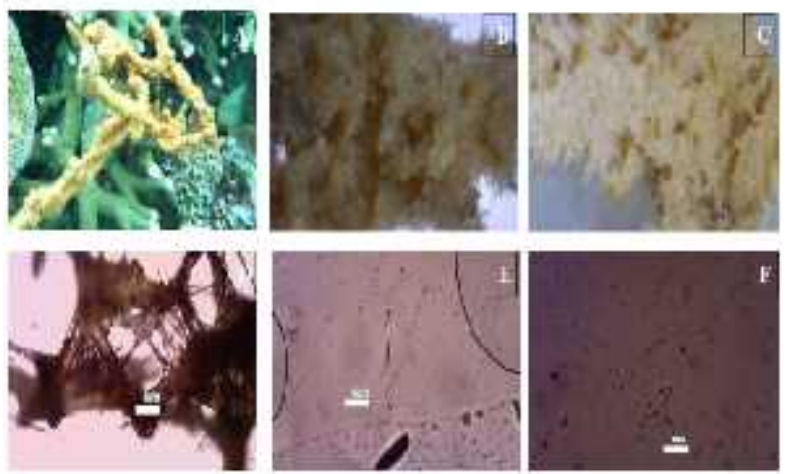

Gambar 5. (A) Bentuk Pertumbuhan: spons bercabangcabang, (B) Konsistensi lembut dan kompresibel, (C) Proyeksi: badan spons yang rapuh saat dikeringkan, (D) Choanosome: Anastoming mengulang seperti kerangka choanosome, (E) Megasclere berbentuk klasik dan (F) Microsclere Chelae microsclere

Umumnya spons kelas Demospongiae dapat ditemukan pada daras laut di kedalaman 3-6 m pada temperatur tidak ekstrim $\left(26^{\circ} \mathrm{C}-31^{\circ} \mathrm{C}\right)$, dengan $\mathrm{pH}$ range 6-7. Hasil analisis morfologi disimpulkan bahwa keempat sampel merupakan spons kelas Demospongiae, (Tabel 2), bersesuaian dengan kondisi lingkungan sampling (Tabel1). Umumnya spons kelas Demospongiae memiliki bentuk tubuh sangat bervariasi yaitu ada yang menyerupai kipas, batang, terompet dan lainnya, hewan ini sebagian membentuk koloni yang sering tampak tidak teratur sehingga tampak sebagai tumbuhan. Warnanya bermacam-macam dan dalam tubuhnya mengandung ganggang yang memiliki warna dan mereka mengadakan simbiosis, (Ismet, et al., 2011; Hooper, 2003). Sponge dapat berbentuk sederhana seperti tabung dengan dinding tipis, atau massif bentuknya dan agak tidak teratur. Banyak sponge juga terdiri atas segumpal jaringan yang tak tentu bentuknya, menempel dan membuat kerak pada batu, cangkang, tonggak, atau tumbuh-tumbuhan, (Marzuki, et al., 2014; Pawar, at al., 2017). Morfologi luar sponge dipengaruhi oleh faktor fisik, kimiawi, dan biologis serta lingkungan sebagai tempat perkembangbiakan. Spesimen spons yang berada di lingkungan terbuka dan berombak cenderung memiliki pertumbuahn pendek dan dapat merambat, sebaliknya spons jenis spesies sama, jika berada pada lingkungan terlindung atau pada perairan lebih dalam serta berarus tenang, biasanya memiliki pertumbuhan cenderung tegak dan tinggi, (Uli, et al., 2017; Marzuki, et al., 2014).

Spons Petrosia (Strongylophora) corticata (K.Sampel: Sp 1), dengan ciri bentuk pertumbuhan berupa kulit berbentuk cerobong dengan oscular tinggi, tampak cerah dengan warna coklat muda, berkonsistensi tegas dan kuat, bentuk permukaan tidak rata, berlendir tipis dan halus, dengan kerangka berupa spicule multi, kerangka dengan serat sedikit, padat dan memiliki spicule tipe megasclere, (Gambar 2), (Morrow, et al., 2015; Hooper and Van, 2002; Hooper, J.N.A. 2000). Spons spesies Niphates sp, (K.Sampel Sp 2) memiliki bentuk pertumbuhan melingkar dengan Oscula ukuran besar, konsistensi permukaan tubuh licin ditutupi lumpur menyerupai lendir. Tubuh spons tersebut tidak elastis dan rapuh, memiliki kerangka spicule echinating berupa pilar membentuk trapesium berserat, dan memiliki oxea ukuran kecil, (Gambar 3), (Morrow, et al., 2015; Hooper and Van, 2002). Kedua jenis spons di atas merupakan spons ordo Haclosclerida kelas Demospongiae.

Spons Petrosia (Strongylophora) corticata yang memiliki lendir dan Niphates sp tubuh licin ditutupi lumpur menyerupai lendir merupakan kekhasan kedua jenis spons tersebut yang mengindikasikan bahwa spons ini dapat menggunakan karbon sebagai sumber energy. Kedua jenis spons tersebut juga berpotensi bersimbion dengan mikroorganisme, (Marzuki, et al., 2014). Mikroorganisme ini mampu memproduksi zat berkarakter enzim yang dapat digunakan untuk melingdungi tubuh spons agar terhindar dari paparan zat toksik hidrokarbon jenis aromatik, Marzuki, et al., 2015b; 2015c; 2016b).

Sampel spons berikutnya adalah spesies Hyrtios erectur, (K.Sampel Sp3) family Thoerectidae, ordo Dictyoceratida, juga merupakan spons kelas Demospongiae dengan bentuk pertumbuhan bercabang dua, 
jika berkumpul terlihat berwarna hitam, namun karakteristik khusus tidak teridentifikasi, sedangkan permukaan membentuk piramida, dengan kerangka menempel berupa serabut, spicule berupa substylostyle, (Gambar 4), (Marzuki, et al., 2016; Hooper and Van, 2002). Gambar 5, (K.Sampel Sp. 4) merupakan spons spesies Clathria (Thalysias) reinwardti, family Microcionidae dengan ciri-ciri bentuk pertumbuhan bercabang-cabang, konsistensi lembut dan kompresibel, sedangkan badan spons jenis ini rapuh apabila kering dan anatomi choanosome berupa Microsclere Chelae, (Marzuki, et al., 2016a; Morrow, et al., 2015; Hooper and Van, 2002).

Data morfologi jenis spons yang diperoleh pada Kepulauan Kodingareng Keke, Gugusan Kepulauan Spermonde, dari empat jenis sampel yang dianaisis, dua diantaranya (K.Sampel Sp 1 dan Sp 2) dan mendegradasi komponen hidrokarbon. Komponen spons yang berpotensi sebagai biodegradator hidrokarboan adalah sel biomassa spons dan mikroorganisme yang bersimbion dengan tubuh spons secara komensalisma, (Pawar, et al., 2017; Marzuki, et al., 2016a; Ismet, et al., 2011). Penciri kedua jenis spons tersebut berpotensi mengedradasi hidrokarbon dapat dilihat pada permukaan tubuh yang berlendir atau diselimuti lumpur. Untuk memastikan bahwa spons Petrosia (Strongylophora) corticata dan Niphates sp mampu mendegradasi hidrokarbon, dapat dilakukan dengan mengekstrak biomassa spons dan mengisolasi mikrosimbion spons tersebut, lalu diaktifkan, kemudian diujikan pada area yang tercemar hidrokarbon yang telah diketahui konsentrasinya pada skala laboratorium, (Marzuki, et al., 2017; 2016b).

Metode yang dilakukan untuk mendegradasi hirokarbon menggunakan biomassa spons atau isolat bakteri dari spons dilakukan dengan kontak antara isolat yang telah diaktifkan dalam sebuah reaktor degradasi yang sederhana. Kinerja mikrosimbion dalam mereduksi hidrokarbon dapat dilihat setelah beberapa hari masa kontak dengan melihat parameter pertumbuhan sel bakteri, kerapatan optik media degradasi, kelimpahan komponen hidrokarbon dan konsentrasi hidrokarbon yang tidak terdegradasi, (Pawar, et al., 2017; Marzuki, et al, 2015b; 2015c). Umumnya spons cenderung memiliki morfologi yang berbeda, jika hidup pada dua lingkungan yang berbeda, berakibat sifat, jenis mikroorganisme dan jumlah simbion yang dapat dilakukan berbeda. Faktor, seperti nutrient, arus laut, tingkat cemaran pada laut tempat perkembangbiakan, jenis cemaran dan intensitas ancaman terhadap kehidupan spons diduga sebagai penyebab perbedaan tersebut. Karakteristik utama yang mencirikan kedua jenis spons tersebut mampu mendegradasi hidrokarbon dilihat pada struktur tubuh adalah kandungan lendir atau lumpur yang ada dalam tubuh, maupun yang menyelimuti tubuh spons. Lendir ini mengandung bakteri yang bertugas memproduksi sejumlah zat berperilaku seperti enzim diproduksi oleh mikrosimbion sebagai sebagai respon atas ancaman yang dialami oleh spons, sehingga spons yang hidup pada area tercemar hidrokarbon dapat bertahan hidup, (Pawar, et al., 2017; Marzuki, et al., 2016a).

\section{KESIMPULAN}

Berdasarkan data di atas disimpulkan:

(1) Dua macam specimen spons spesies sama, yang diperoleh dari dua tempat yang berbeda, kecenderungan memiliki morfologi yang berbeda, demikian pula sifat, jenis mikroorganisme dan jumlah simbion yang terjadi.

(2) Analisis morfologi empat jenis spons yang diperoleh dari Pulau Kodingareng Keke, Kepulauan Spermonde, Sulawesi Selatan, menunjukkan bahwa hanya ada dua jenis spons yang berpotensi dapat mendegradasi komponen hidrokarbon. Kedua jenis spon tersebut adalah Petrosia (Strongylophora) corticata dan Niphates sp.

(3) Karakteristik utama yang mencirikan kedua jenis spons mampu mendegradasi hidrokarbon dilihat pada struktur tubuh, yakni: memiliki lendir atau lumpur yang ada dalam tubuh maupun yang menyelimuti tubuh spons. Lendir ini mengandung bakteri yang bertugas memproduksi sejumlah zat berkarakter enzim sebagai respon atas ancaman yang dialami oleh spons, sehingga spons yang hidup pada area tercemar hidrokarbon dapat bertahan hidup.

\section{REFERENSI}

Hausmann, Rudolf., Marco P. Vitello, Frank Leitermann and Christoph Syldatk, 2006. Advances in the production of sponge biomass Aplysina aerophoba-A model sponge for ex situ sponge biomass production. Journal of Biotech., vol. 124, hal. 117-127

Hooper, J.N.A. 2000. Sponguide: guide to sponge collection and identification. Queensland: Queensland Museum. 
Hooper, J.N.A., and W.M. Van Soest (Ed.). 2002. Systema Porifera: a guide to the classification of sponges. New York: Kluwer Academic/Plenum Publishers.

Ismet, S.M., Soedharma, D., Effendi, H., 2011. Morfologi dan Biomassa Sel Spons Aaptosaaptos dan Petrosia sp., Jurnal Ilmu dan Teknologi Kelautan Tropis: vol. 3, nomor 2, hal. 153-161

Marzuki, Ismail., Hadija, E. Ismail., La Nafie, Nursiah., Dali, Seniwati., 2017. Study Biodegradation of Aromatics Pyrene Using Bacterial Isolates from the Sea and micro symbionts Sponges, International Journal of Applied Chemistry (IJAC), vol. 13, nomor 3, hal. 707-720 https://scholar.google. co.id/citations? hl=en\&user=AjWcdX8AAAAJ

Marzuki, Ismail., Noor, Alfian., La Nafie, Nursiah., Djide, M. Natsir, 2016a. Morphological and Phenotype Analysis of Microsymbiont and Biomassa Marine Sponge From Beach, Balikpapan, East Kalimantan, International Journal Marina Chimica Acta, vol. 17, nomor 1, hal. 8-15. https://scholar. google.co.id/citations?hl=en\& user=AjWcdX8AAAAJ

Marzuki, Ismail., 2016b. Sponges Micro symbiont callyspongia sp as Biomaterials Degrading Hydrocarbons", Proceedings of the National Seminar on Chemistry, Lombok-Mataram, Indonesia. ISBN 978-979-8911-97-2, Nomor 1, hal 480-450, https://scholar.google.co.id/citations? $\mathrm{hl}=\mathrm{en} \& u s e r=\mathrm{Aj}$ WcdX8AAAAJ

Marzuki, Ismail., Noor, Alfian., La Nafie, Nursiah., Djide, M. Natsir, 2015a. Molecular characterization of gene 16S rRNA micro symbionts in sponge at Melawai Beach, East Kalimantan, International Journal Marina Chimica Acta, vol. 16, nomor 1, hal. 38-46; https://scholar.Google .co.id/citations?hl=en \&user=AjWcdX8AAAAJ

Marzuki, Ismail., Noor, Alfian., La Nafie, Nursiah., Djide, M. Natsir, 2015b. Sponge Role In, Alleviating Oil Pollution Through Sludge Reduction, A Preliminary Approach, International Journal of Applied Chemistry (IJAC, vol. 11, nomor 4, hal. 427-441, https://scholar.google.co.id/citations?hl=en\&user= AjWcdX8AAAAJ

Marzuki, Ismail., Noor, Alfian., La Nafie, Nursiah., Djide, M. Natsir, 2015c. The Potential Biodegradation Hydrocarbons of Petroleum Sludge Waste by Cell Biomass Sponge Callyspongia sp., International Journal Marina Chimica Acta, vol. 16, nomor 2, hal. 11-20, https://scholar. google.co.id/citations?hl=en\& user=AjWcdX8AAAAJ

Marzuki, Ismail., Noor, Alfian., La Nafie, Nursiah., Djide, M. Natsir, 2014. Isolation and Identification on Degradator Bacterial of Petroleum waste which Symbionts with Sponge Callyspongia sp from Melawai Beach. Proceeding: International Conference on the sciences (ICOS), Makassar, South Sulawesi, Indonesia, ISBN: 9786027219809, nomor 1, hal. 493-503; https://scholar.google.co.id /citations ?hl=en\&user=AjWcdX8AAAAJ

Menggelea, P. F., Posangi, J., Wowor, P. M., Bara, R., 2015. Uji Efek Antibakteri Jamur Endosimbion Spons Laut Callyspongia sp Terhadap Bakteri Pseudomonas aeruginosa dan Eschericia coli, Jurnal e-Biomedik (eBm): vol. 3, nomor 1, hal. 376-380

Morrow, Christine and Cardenas, Paco. 2015. Proposal for a revised classification of the Demospongiae (Porifera). Frontier in Zoology, vol. 12, nomor 7 (update)

Romimohtarto, K \& Juwana, S., 2001. Biologi Laut, Ilmu Pengetahuan Tentang Biota Laut, Pusat Penelitian dan Pengembangan Oseanologi-LIPI. Jakarta. pp. 115-128

Pawar, R. P., Mohammad, R. A. S. Al-Tawakal., 2017. Marine sponges as Bioindicator species of Environmental Stress at Uran (Navi Mumbai), west coast of India. American Eurasian Journal of Sustainable Agriculture, vsol. 11, nomor 3, hal. 29-37, http://www.aensiweb.com/AEJSA/

Steindler, L. D. Huchon, A. Avni, dan M. Ilan. 2005. 16S rRNA phlogeny of sponges-associated cyanobacteria. Apll Environ Microbiol, vol. 71, nomor 7, hal. 4127-4131

Thakur, Narsinh L. and Werner E.G. Muller, 2004. Biotechnological potential of marine sponges. Curr. Sci., vol. 86, nomor 11, hal. 1506-1512

Uli, Hanafi., Noor, Alfian., Mandey, W. Frederik., Sapar, Ajuk., 2017. Isolation, Identification and Bioactivitytest of Non Polar Compound on n-Hexane Extract of Haliclona (Reniera) Fascigeral From Samalona Island-Spermonde Archipelago, International Journal Marina Chimica Acta: vol. 17, nomor 2, hal. 32-41 


\section{UCAPAN TERIMA KASIH}

Terima kasih disampaikan kepada Kemenristekdikti, c.q Direktorat Riset dan Pengabdian kepada Masyarakat yang telah membiayai penelitian ini dalam skema Penelitian Produk Terapan (PPT) tahun 2017, sehingga penelitian ini dapat dilaksanakan. 